\title{
Estimation and comparison of different lactation persistency methods in Tharparkar cattle
}

\author{
Linda George ${ }^{1}$, ID Gupta $^{1}$, AK Gupta $^{1}$, Vineeth MR ${ }^{1}$, Jaismon PAchankunju ${ }^{2}$ and Aruna TS $^{3}$
}

Received: 02 March 2021 / Accepted: 20 April 2021 / Published online: 27 July 2021

(C) Indian Dairy Association (India) 2021

\begin{abstract}
The present study was undertaken to evaluate the various measures of lactation persistency and to estimate effect of various non-genetic factors affecting the persistency of milk production and comparison of different persistency indices using standard error as percentage of mean in Tharparkar cattle. A total of 322 lactation records of 138 Tharparkar cattle were collected from history cum pedigree sheet maintained at Animal Genetics and Breeding Division of National Dairy Research Institute, Karnal from 1996 to 2018 for the estimation of lactation persistency. Lactation persistency was estimated by using Ratio method (P1), Prasad method (P2), Solkner and Fuchs variation method in 200 days (P3) and 305 days (P4). The least squares means for persistency of milk yield were $149.6 \pm 3.07,0.53 \pm 0.007$, $1.83 \pm 0.05$ and $2.28 \pm 0.07$ in $\mathrm{P} 1, \mathrm{P} 2, \mathrm{P} 3$ and $\mathrm{P} 4$ respectively in Tharparkar cattle. Based on standard error as percentage of mean, the best method was Prasad method (1.1\%). The highest values of least squares means were found for first calvers in P1 but in P3 and $\mathrm{P} 4$ fourth calvers were more persistent. The cows calved during rainy season were more persistent as estimated by $\mathrm{P} 1$ and $\mathrm{P} 2$ but based on $\mathrm{P} 3$ and $\mathrm{P} 4$ winter calvers were more persistent. There was a highly significant $(\mathrm{P}<0.05)$ positive correlation of total milk yield with all the method of persistency indices.
\end{abstract}

Keywords: Non-genetic factors, Lactation persistency, Standard error as percentage of mean, Tharparkar cattle

${ }^{1}$ Division of Animal Genetics and Breeding, ICAR- National Dairy Research Institute, Karnal- 132001, Haryana, India

${ }^{2}$ Division of Animal Biostatistics, ICAR-Indian Veterinary Research Institute, Izatnagar-243122, UP, India

${ }^{3}$ Division of Animal Genetics and Breeding, ICAR- Indian Veterinary Research Institute, Izatnagar-243122, UP, India

Linda George $(\bowtie)$

Animal Genetics and Breeding Division, , ICAR- National Dairy Research Institute, Karnal- 132001, Haryana, India

Email: lindagpaliyath@gmail.com

\section{Introduction}

The important norm for productivity of any lactating cow is maintenance of peak yield for a longer period. Milk yield in cows steadily increases for first 45-90 days after parturition, remains stable for a few weeks and then declines. This trend of milk yield is called lactation curve (Rakes et al. 1963). Lactation curve passes through different phases, one among them is persistency. Persistency may be defined as number of days during which the level of constant yield is maintained (Grossman et al. 1999). Highly persistent cows are relatively higher milk producers and have longer productive life (Narain and Dutta 1981; Malhotra et al.1984; Ramchandraiah et al.1990)

The effect of different non-genetic factors like, season, lactation order and period of calving on persistency was estimated. Different measures of persistency indices had shown wide range of heritability estimates from low to medium with high standard error. The positive correlation of production traits with measures of persistency indices showed association and usefulness of persistency measure. So, high degree of persistency during the first lactation is desirable and can be used as one of the selection criteria for dairy animals (Narain and Dutta 1981)

However, till date no attempt has been made to study the measures of persistency indices and the environmental factors influencing the indices in Tharparkar cattle. Therefore, the present work is an attempt to study these phases of persistency of milk production in Tharparkar cattle.

\section{Materials and Methods}

The relevant data for this study was collected from 322 lactation records (305-day/less) irrespective of the lactation order of 138 Tharparkar cows from history-cum-pedigree sheets maintained at Livestock record unit, Animal Genetics and Breeding Division of National Dairy Research Institute, Karnal from 1996 to 2018 (22 years). The normal lactation was considered as the period of milk production by a cow for at least 100 days and more than 500 $\mathrm{kg}$ milk yield. Lactation order was classified as first, second, third and fourth and later lactations. Each year was classified into four seasons namely winter (December-March), summer (April-June), 
rainy (July-September) and autumn (October-November) based on agro-climatic conditions. In order to examine the effect of year of calving on persistency of lactation, the data of 22 years from 1996 to 2018 was divided into four periods (1996-2002, 20032008, 2009-2013, 2014-2018).

Estimation of Persistency Indices:

Different methods of measurement of persistency used in this study are as follows:

Rao and Sundaresan (1982) method:

$\mathrm{P}=\frac{\text { Lactation milk yielc }}{\text { Peak yield }}$

Prasad method (1999):

A new measure of persistency estimation in which area under lactation curve during post peak period was taken into consideration:

$\mathrm{P}=\frac{\text { Milk production during post peak period }}{\text { Peak yield } \mathrm{X} \text { post peak period }}$

$\mathrm{P}=\frac{\text { Average milk production during post peak period. }}{\text { Peak yield }}$

Solkner and Fuchs method (1987):

SD2 $=$ Standard deviation of test-day milk yields (200 days)

SD3 $=$ Standard deviation of test-day milk yields (300 days)

The data used in the present study had unequal sub-class frequencies. Disproportionate sub-class frequencies caused the different classes of effects to be non-orthogonal.

The data was classified into different lactation order, seasons, period of calving and were adjusted using Least-squares analysis, as described by Harvey (1990) model:

$$
\mathrm{Y}_{\mathrm{ijk}}=\mu+\mathrm{P}_{\mathrm{i}}+\mathrm{S}_{\mathrm{j}}+\mathrm{PC}_{\mathrm{k}}+\mathrm{e}_{\mathrm{ijk}}
$$

Where,

$\mathrm{Y}_{\mathrm{ijk}}=$ Observation on the $\mathrm{n}^{\text {th }}$ individual born in $\mathrm{i}^{\text {th }}$ parity, $\mathrm{j}^{\text {th }}$ season, $\mathrm{k}^{\text {th }}$ period of calving

$\mu \quad=\quad$ Overall population mean

$\mathrm{P}_{\mathrm{i}} \quad=\quad$ Effect of $\mathrm{i}^{\text {th }}$ parity

$\mathrm{S}_{\mathrm{j}} \quad=\quad$ Effect of $\mathrm{j}^{\text {th }}$ season

$\mathrm{PC}_{\mathrm{k}}=$ Effect of $\mathrm{k}^{\text {th }}$ period of calving $\mathrm{e}_{\mathrm{ijk}}=$ Random error, assumed to be normally and independently distributed with mean zero and constant variance i.e. $\operatorname{NID}\left(0, \sigma_{\mathrm{e}}^{2}\right)$

DMRT modified by Kramer (1957) was used for testing differences among least-squares means. The correlation of persistency indices with peak yield and lactation milk production was estimated by standard correlation formula using SPSS (2001) statistical package for social science.

\section{Results and Discussion}

\section{Estimation of persistency indices by different methods:}

The persistency indices were estimated by four different methods viz. P1: Ratio method (Rao and Sundaresan, 1982), P2: Prasad method (Prasad et al. 1999), P3: Solkner and Fuchs variation method in 200 days and P4: Solkner and Fuchs variation method in 305 days (Solkner and Fuchs, 1987). The overall least squares means for persistency of milk yield was $149.6 \pm 3.07,0.53 \pm 0.007$, $1.83 \pm 0.05$ and $2.28 \pm 0.07$ in P1, P2, P3 and P4 respectively in Tharparkar cattle (Table 3 ).

The overall least squares mean estimate of persistency by Ratio method of Rao and Sundaresan (1982) was 174.79 and that of Bhutia and Pandey (1989) was 185.14 in Holstein-Friesian crosses. Kumar and Singh $(2004,2006)$ assessed average persistency as $215.09 \pm 2.88$ and $207.88 \pm 2.18$ in Karan Fries cows. These findings were higher than our estimate in Tharparkar cattle. In Sahiwal cattle low lactation persistency of $87.86 \pm 1.61$ reported by Sachan et al. (2020) and $194 \pm 1.10$ was reported by Kaushal et al. (2016).

When compared Prasad method the least square mean of $0.53 \pm$ 0.007 in Tharparkar cattle was lesser than the estimates found in Karan Fries cattle $(0.68 \pm 0.00)$ by Kumar and Singh (2006) and in Crossbred HF (0.621 \pm 0.09$)$ by Sharma et al. (2018).

The persistency estimates using Solkner and Fuchs (200 days and 305 days) methods were $1.83 \pm 0.05$ and $2.28 \pm 0.07$ respectively in Tharparkar cattle However, using Solkner and Fuchs (1987) persistency estimate were $2.43 \pm 0.005$ (200 days) and $3.08 \pm 0.005$ (305 days) respectively in Simmental cattle.

Atashi et al. (2006) estimated by solkner and Fuchs 305 days method in Holstein Friesian cattle (4.120 \pm 0.0079$)$ which was higher than Tharparkar cattle. Kaushal et al. (2016) in NDRI, Karnal estimated P3 and P4 as $2.29 \pm 0.04$ and $2.20 \pm 0.03$ in Sahiwal cattle.

The effect of various non-genetic factors calculated by least squares analysis of variance using mixed model (model-1), by taking parity, season and period of calving as the fixed effect. The mean sums of squares of each fixed effect are shown in Table 2. The effect of lactation number (parity) was highly significant $(\mathrm{P} \leq 0.01)$ in $\mathrm{P} 1, \mathrm{P} 3$ and $\mathrm{P} 4$ measures of persistency but non-significant in P2 (Table 2). The highest values of least squares 
means (179.41 \pm 5.9$)$ were found for first calvers in P1. But in P3 and P4 fourth calvers were more persistent $(2.15 \pm 0.11)$ and $(2.74$ \pm 0.22 ) (Table 3 ). In P1 first two parities were significantly different from the remaining parities and there was no statistical difference from $3^{\text {rd }}$ parity onwards. But in P3 and P4 first three parities were significantly different and fourth parity onwards no significant difference was observed in persistency.

Significant effect of parity was observed while comparing effect of parity on lactation persistency using different methods in Tharparkar cattle. In different lactations, persistency was increasing from $1^{\text {st }}$ lactation to $4^{\text {th }}$ lactation except in Ratio method. Gill (1971) and Singh and Shukla (1985) noticed that in Hariana and Gir cattle the parity had highly significant effect on persistency. Zurwan et al. (2017) in Sahiwal, Kumar and Singh (2006) in Karan Fries and Fadlelmoula et al. (2007) in crossbred HF observed that persistency decreased by $8-10 \%$ from first to second and third lactation. Persistency of milk yield were continuously increasing from $1^{\text {st }}$ to $4^{\text {th }}$ parity was also reported by Singh and Gopal (1982) in Rathi, Shahare et al. (1988) in HF $\times$ Hariana, Jersey $\times$ Sahiwal, Jersey $\times$ Gaolao and HF $\times$ Gaolao and Patond et al. (2014) in Jersey cattle and Garudkar et al. (2018) in Phule Triveni cattle. Several workers affirmed that first calvers had more persistency than the calvers of subsequent lactations in different cattle breeds and crossbreds (Kumar and Singh 2006; Rao and Sundaresan 1982). In Holstein Friesian cattle the lactation length of a first parity cow was, on average, $7.8,8.6$, and 8.4 days shorter than that of second, third, and fourth parity cows, respectively (William et al. 2021)

The season of calving had highly significant effect $(\mathrm{P} \leq 0.01)$ on $\mathrm{P} 3$ and $\mathrm{P} 4$ and significant effect $(\mathrm{P} \leq 0.05)$ on $\mathrm{P} 1$ but not significant in P2 method (Table 2). The cows calved in the rainy season were more persistent in P1 estimate $(162.6 \pm 6.9)$ and least persistent (140.2 \pm 4.12 ) in winter season calvers (Table 3$)$. The winter and rainy seasons were significantly different from other seasons. But when compared with Solkner and Fuchs method in P3 and P4 winter calvers had more persistency $2.21 \pm 0.06$ and $2.85 \pm 0.11$ respectively.

Season is one of the key factors affecting persistency. The present results on significant effect of season of calving were in agreement with the outcomes of Rao and Sundaresan (1982), Solkner and Fuchs (1987), Kumar and Singh (2004; 2006), Kaushal et al. (2016) in different breeds of cattle. According to Ratio method rainy calvers had more persistency than other seasonal calvers. This may be due to continuous availability of green fodder and less stress due to favourable climate conditions and least persistency in winter season may be due to unfavourable climatic condition, non-availability of green fodder and lack of nutrients. Rao and Sundaresan (1982), Prasad et al. (1999) and Kumar and Singh $(2004 ; 2006)$ also testified that rainy calvers were more persistent and winter calvers were less persistent. Hence, it is inferred that variation in season can cause stress in cattle and leads to reduction in persistency. Solkner and Fuchs (1987) and Sharma et al. (2018) reported high value of persistency measure in winter season for Simmental cattle and Crossbred HF cattle respectively. The scale of measurement in Solkner and Fuchs method is different in such a way that they are measuring the deviation of milk yield from the means. Singh et al. (1965) reported that Hariana cattle which calved in the summer season had more persistency. So based on the breed and their adaptability to different environmental conditions will change therefore they show variation in lactation persistency also. Some workers reported the non-significant effect of season of calving in PhuleTriveni cattle by Garudkar (2018); Jersey breed by Patond et al. (2014); Gir by Shingare et al. (2015) and Jersey x Hariana by Koley et al. (1979). Williams et al. (2021) reported that, the lactation length of cow calving in February, March, or April was, on average, 4.2, 12.7 , and 21.9 days respectively shorter, relative to cows calving in January. By optimised reproductive management and breeding programmes lead to the improved the reproductive performance of the herd thereby increased the proportion of animals calving in earlier months, which would be advantageous to lengthen

Table 1 Standard error as percentage of mean for different measures of persistency indices

\begin{tabular}{lll}
\hline Persistency indices & Measures of persistency & SE as \% Mean \\
\hline Ratio method & P1 & $1.8 \%$ \\
Prasad method & P2 & $1.1 \%$ \\
Solkner and Fuchs variation (200 days) & P3 & $2.1 \%$ \\
Solkner and Fuchs variation (305 days) & P4 & $3.5 \%$ \\
\hline
\end{tabular}

Table 2 Mean sum of squares of different measures of persistency indices

\begin{tabular}{llllll}
\hline Source of variation & D.F & P1 & P2 & P3 & P4 \\
\hline Parity & 4 & $19960.81^{* *}$ & 0.0027 & $7.37^{* *}$ & $5.95^{* *}$ \\
Season & 3 & $7433.18^{*}$ & 0.0087 & $5.78^{* *}$ & $5.90^{* *}$ \\
Period of calving & 5 & $10401.27^{* *}$ & $0.049^{*}$ & $1.27^{*}$ & 1.14 \\
Error & 11 & 2206.51 & 0.0132 & 0.1184 & 0.5492 \\
\hline
\end{tabular}

$(* *=\mathrm{P}<0.01$ and $*=\mathrm{P}<0.05)$ 
Table 3 Parity, Season and period of calving wise least square means and their standard errors for different measures of persistency indices

\begin{tabular}{llllll}
\hline Class & $\begin{array}{l}\text { No. of } \\
\text { observation }\end{array}$ & P1 & P2 & P3 & P4 \\
\hline Mean & 322 & $149.6 \pm 3.07$ & $0.53 \pm 0.007$ & $1.83 \pm 0.05$ & $2.28 \pm 0.07$ \\
& & Parity & & & \\
1 & 72 & $179.41^{\mathrm{d}} \pm 5.9$ & $0.53 \pm 0.01$ & $1.22^{\mathrm{a}} \pm 0.08$ & $1.42^{\mathrm{a}} \pm 0.14$ \\
2 & 77 & $152.45^{\mathrm{c}} \pm 5.5$ & $0.53 \pm 0.01$ & $1.74^{\mathrm{b}} \pm 0.08$ & $2.16^{\mathrm{b}} \pm 0.15$ \\
3 & 46 & $143.84^{\mathrm{b}} \pm 6.9$ & $0.52 \pm 0.01$ & $1.93^{\mathrm{c}} \pm 0.11$ & $2.43^{\mathrm{c}} \pm 0.19$ \\
4 & 45 & $132.1^{\mathrm{a}} \pm 7.23$ & $0.54 \pm 0.01$ & $2.15^{\mathrm{d}} \pm 0.11$ & $2.74^{\mathrm{d}} \pm 0.22$ \\
5 to 8 & 81 & $140.26^{\mathrm{b}} \pm 5.8$ & $0.54 \pm 0.01$ & $2.11^{\mathrm{d}} \pm 0.09$ & $2.68^{\mathrm{d}} \pm 0.15$ \\
& & Season & & & \\
Winter & 139 & $140.2^{\mathrm{a}} \pm 4.12$ & $0.54 \pm 0.01$ & $2.21^{\mathrm{a}} \pm 0.06$ & $2.85^{\mathrm{a}} \pm 0.11$ \\
Summer & 95 & $153.3^{\mathrm{b}} \pm 4.8$ & $0.53 \pm 0.01$ & $1.74^{\mathrm{b}} \pm 0.07$ & $2.26^{\mathrm{b}} \pm 0.12$ \\
Rainy & 47 & $162.6^{\mathrm{c}} \pm 6.9$ & $0.54 \pm 0.01$ & $1.58^{\mathrm{c}} \pm 0.11$ & $1.75^{\mathrm{c}} \pm 0.18$ \\
Autumn & 40 & $142.26^{\mathrm{a}} \pm 7.5$ & $0.51 \pm 0.01$ & $1.78^{\mathrm{b}} \pm 0.11$ & $2.27^{\mathrm{b}} \pm 0.20$ \\
& & Period of calving & & & \\
$1996-2002$ & 94 & $164.6^{\mathrm{c}} \pm 5.2$ & $0.53^{\mathrm{b}} \pm 0.01$ & $1.73^{\mathrm{a}} \pm 0.07$ & $2.17 \pm 0.12$ \\
$2003-2008$ & 74 & $145.8^{\mathrm{b}} \pm 5.7$ & $0.51^{\mathrm{a}} \pm 0.01$ & $1.85^{\mathrm{b}} \pm 0.09$ & $2.36 \pm 0.14$ \\
$2009-2013$ & 62 & $135.3^{\mathrm{a}} \pm 6.2$ & $0.53^{\mathrm{b}} \pm 0.01$ & $2.04^{\mathrm{c}} \pm 0.10$ & $2.56 \pm 0.19$ \\
$2014-2018$ & 91 & $152.5^{\mathrm{b}} \pm 5.3$ & $0.57^{\mathrm{c}} \pm 0.01$ & $1.70^{\mathrm{a}} \pm 0.08$ & $2.04 \pm 0.15$ \\
\hline
\end{tabular}

Superscripts are based on the significant difference between the levels for each non-genetic factors which are significant at $\mathrm{P}<$ 0.01 or $\mathrm{P}<0.05$

Table 4 Phenotypic correlation of lactation persistency with production traits

\begin{tabular}{lllll}
\hline Production traits & $\mathrm{P} 1$ & $\mathrm{P} 2$ & $\mathrm{P} 3$ & $\mathrm{P} 4$ \\
\hline TMY & $0.641^{* *}$ & $0.28^{* *}$ & $0.16^{* *}$ & $0.49^{* *}$ \\
$\mathrm{~L}$ & $0.741^{* *}$ & $0.23^{* *}$ & -0.11 & $-0.17^{*}$ \\
$\mathrm{PY}$ & 0.035 & $-0.22^{* *}$ & $0.75^{* *}$ & $0.87^{* *}$ \\
\hline
\end{tabular}

$(* *=\mathrm{P}<0.01$ and $*=\mathrm{P}<0.05)$

lactations and milk yield. These achievements, the effect of function of seasonal-calving systems where all cows tend to be dried off in early winter thereby escape from winter stress. (Berry et al. 2014; Ma et al. 2019).

The effect of period of calving was highly significant $(\mathrm{P} \leq 0.01)$ in $\mathrm{P} 1$ and significant $(\mathrm{P} \leq 0.05)$ in $\mathrm{P} 2$ and $\mathrm{P} 3$ but not in $\mathrm{P} 4$ (Table 2). In P1 method, 1996-2002 period had shown more persistency while in P2 method, 2014-2018 and in P3 method, 2009-2013 period had shown more persistency. On comparison the lowest persistency during 2009-13, 2003-2008, 2014-18 periods was observed in P1, $\mathrm{P} 2$ and $\mathrm{P} 3$ respectively.

The present findings of significance of period of calving in Tharparkar cattle were in support with that of Tekerli et al. (2000), Rekik et al. (2003), Kumar and Singh $(2004 ; 2006)$ and Fadlelmoula et al. (2007) in different crossbred and exotic cattle and Kaushal et al. (2016) in Sahiwal cattle. No regular trend in different measures of persistency was observed over different periods. There was a change in climate, managemental practices and genetic variations that caused difference in performance from 1996 to 2018. The effect of each non-genetic factor on different persistency estimation methods is diverse. So, different level of significance was obtained in each period. Period of calving had no significant effect on persistency of lactation was reported by Koley et al. (1979) in Jersey x Hariana crossbred; Gupta and Johar (1982) in Tharparkar; Zaman et al. (1994) in Jersey cattle and Patond et al. (2014) in Jersey cross.

\section{Comparison of different methods of estimation of persistency}

Different indices for estimation of persistency were compared on the basis of standard error (SE) expressed as percent of population mean. The lower the SE expressed as percent of population mean, the higher would be efficiency of the persistency parameters (Kaushal et al. 2016). When compared all the indices Prasad method had the least SE as percentage of mean therefore, it was the best of persistency index based on the data (Table 1). The ratio method (P1and P2) has the least SE as percentage of mean when compared with variation method.

\section{Correlation of persistency indices with production traits}

There was positive significant correlation $(\mathrm{P} \leq 0.01)$ of total milk yield (TMY) with P1, P2, P3 and P4. The correlation between 
lactation length (LL) and $\mathrm{P} 1, \mathrm{P} 2$ were highly significant $(\mathrm{P} \leq 0.01)$ and correlation between peak yield (PY) and P2, P3 and P4 were also highly significant $(\mathrm{P} \leq 0.01)$. There was significant negative correlation between peak yield and Prasad method of estimation and also significant negative correlation between Solkner and Fuchs 305 day's method with lactation length (Table 4). In Tharparkar cattle, highly significant positive correlation of lactation persistency with total milk yield (TMY) was found, similar results were reported by Saxena and Kumar (1960), Shewta (2018) and Sharma and Bhatnagar (1972) in Sahiwal cattle as 0.79, 0.5 and $0.56 \pm 0.4$ respectively and Gill et al. (1971) in Hariana cattle $(0.36 \pm 0.02)$ and Shingare et al. (2015) found in Deoni cattle $(0.60 \pm 0.47)$. In Tharparkar cattle negative correlation of peak yield with lactation persistency was found for Prasad method and similar results were reported by Gill et al. (1971) and Singh et al. (1965) in Hariana cattle ( -0.007 and -0.16 respectively). Positive correlation of peak yield with lactation persistency was stated by Torshiz (2016), Gupta and Johar (1982) and Sharma and Bhatnagar (1972) in different indigenous and crossbred cattle. In most of the reports lactation length have positive correlation with lactation persistency similar to Tharparkar cattle but persistency estimation using Solkner and Fuchs (200 and 305 days) method had negative correlation with lactation length.

\section{Conclusions}

The present investigation was conducted to study the persistency of milk production and comparison of different estimation methods based on least standard error as percentage of mean in Tharparkar cattle and effect of different non-genetic factors affecting the persistency. The overall least squares means for persistency of milk yield was $149.6 \pm 3.07,0.53 \pm 0.007,1.83 \pm$ 0.05 and $2.28 \pm 0.07$ in P1, P2, P3 and P4 respectively in Tharparkar cattle. When compared all the indices, Prasad method had the least $\mathrm{SE}$ as percentage of mean therefore it was the best of persistency index based on the data. All the non-genetic factors were significant in Ratio and Solkner and Fuchs (200 days) methods of estimation but only period of calving was significant in Prasad method. In Solkner and Fuchs 305 days' variation method, all the non-genetic factors except period of calving was significant. In Tharparkar cattle, first calvers had more persistency than continuing parity and high positive correlation of persistency methods with total milk yield shows the significance of persistency. So lactation persistency may be used as selection criteria for the selection of best producing animals.

\section{Acknowledgments}

The authors are very thankful to the National Dairy Research Institute, Karnal and Animal Genetics and Breeding Division for providing the animal milk production data and required facilities to accomplish this research project.

\section{Compliance with ethical standards}

The research plan was approved by NDRI institutional Animal Ethics committee as per CPCSEA rules.

\section{Reference}

Atashi H, Shahrbabak M, Abdolmohammadi A (2006) Study of some suggested measures of milk yield, persistency and their relationships. Int J Agric Biol 8: 387-390

Berry DP, Wall E, Pryce JE (2014) Genetics and genomics of reproductive performance in dairy and beef cattle. Animal 8:105-21

Bhutia ST, Pandey RS (1989) A note on comparative study of persistency and its association ship with peak and total yield in dairy cattle. Indian J Dairy Sci 42:1

Fadlelmoula AA, Yousif IA, Abu Nikhaila AM (2007) Lactation Curve and Persistency of Crossbred Dairy Cows in the Sudan. J Appl Sci Res 3: 1127-1133

Garudkar SR, Pachpute ST and Deokar DK (2018) Studies on Persistency of Milk Yield and Its Association with Production Traits in Phule Triveni Synthetic Cow. Int J Curr Microbiol App Sci 6: 1585-1589

Gill GS, Balaine DS, Acharya RM (1970) Persistency and peak yield in Hariana cattle. 1. Effect of environmental and physiological factors. Indian J Anim Sci 40: 563-568.

Gill GS, Balaine S, Acharya RM (1971) Persistency and peak yield in Hariana cattle. 2. Phenotypic and genetic parameters. Indian J Anim Sci

Grossman M, Hartz SM, Koop's WJ (1999) Persistency of lactation yield: a novel approach. Indian J Dairy Sci 82: 2192-2197

Gupta LR, Johar KS (1982) Genetic and non-genetic factors affecting persistency of first lactation in Tharparkar cattle. Indian J Dairy Sci 35: 99-101

Harvey WR (1990) User's Guide for LSMLMW, Mixed Model LeastSquares and Maximum Likelihood Computer Programme. Ohio State University, Columbus, Mimeo

Kaushal S, Gandhi RS, Singh A, Chaudhari MV, Prakash V and Gupta A (2016) Efficiency of various measures of persistency of milk yield in Sahiwal cattle. Indian J Anim Res 50: 268-270

Koley Chaudhary G, Mitra DK (1979) Persistency of lactation yield in Jersey, Hariana crossbred cows. Indian J Dairy Sci 32: 302-305

Kramer CY (1957) Extension of multiple range test to group correlated adjusted means. Biometrics 13: 13-18

Kumar A, Singh A (2004) Genetic evaluation of peak yield and its relationship with persistency and lactation milk production in Karan Fries cattle. Indian J Dairy Sci 57: 416-420

Kumar A, Singh A (2006) Genetic and Environmental factors influencing persistency of milk production in Karan Fries cattle. Indian J Anim Res 40: 95-100

Ma L, Cole JB, Da YA, Van Raden PM (2019) Symposium review: genetics, genome-wide association study, and genetic improvement of dairy fertility traits. J Dairy Sci 102:3735-3743

Malhotra PK, Dutta OP and Malhotra JC (1984) Persistency of milk yield of Murrah buffaloes registered in herd book under village conditions. Indian J Anim Sci 54: 145-148

Narain P, Dutta OP (1981) Inheritance of part-lactation and estimation of persistency of milk yield in Sahiwal cattle. Indian J Anim Gen Breed 3: 4-10

Patond MN, Khutal BB, Pachpute ST, Ramod SS (2014) Effect of nongenetic factors on persistency of milk yield in Jersey cattle. Vet Sci Res J. 5: 1-4 
Prasad S, Singh R, Bisht GS (1999) Measure of persistency and its relationship with peak yield and lactation milk yield. Indian J Dairy Sci 52: 308-314

Rakes JM, Stallcup OT, Gifford W (1963) Persistency and the lactation curve of dairy cows, Agricultural Experiment Station, Division of Agriculture, University of Arkansas, Fayetteville, Ark

Ramchandraiah K, Kumar KS, Srocmanoaryana O (1990) A study of lactation persistency in relation to certain economic traits in purebred Jersey cows. Indian J Dairy Sci 43: 270-273

Rao MK, Sundaresan D (1982) Factors affecting the shape of lactation curve in Friesian x Sahiwal crossbred cows. Indian J Dairy Sci 35: $160-167$

Rekik B, Ben Gara A, Ben Hamouda M, Hammami H (2003) Fitting lactation curves of dairy cattle in different types of herds in Tunisia. Livest Prod Sci 83: 309-315

Sachan S, Gupta ID, Verma A, Gupta AK, Vineeth MR and Kumar A (2020) Association of lactation persistency with genetic variants of bovine growth hormone gene in Indian Sahiwal cows Indian J Anim Sci 90: 739-743

Saxena PN, Kumar S (1960) Persistency of milk yield in Sahiwal cows. Indian J Dairy Sci 13: 45-60

Shahare RB, Ali SZ, Tingare SB (1988) Genetic and non-genetic factors affecting persistency of lactation in crossbred cows. Indian J Anim Prodn Mgmt 4: 36

Sharma N, Narang R, Kashyap N, Kumari S, Kaur S, Ratwan P (2018) Genetic analysis of persistency in HF crossbreed cattle at an organised farm of northern India. Trop Anim Health Prod 50:1219-1225

Sharma RC (1972) Inheritance of persistency index and relationship of production traits to persistency index in Sahiwal, Red Sindhi and
Brown Swiss crossbred cows. M.Sc. dissertation submitted to Panjab University, Chandigarh, India.

Shingare VM, Chauhan DS, Bhise BR, Ghosh N (2015) Estimates of Genetic Parameters and Trends of Lactation Performance Traits of Deoni Cattle. Theriogenol Insight-An Int J Reprod Anim 5: 69-79

Singh J, Shukla, KP (1985) Factors affecting persistency of milk production in Gir cattle. Indian Vet J 62: 888-894

Singh RP, Gopal R (1982) Persistency and peak yield of cattle in a rural area. Ind J Anim Sci 52: 487-489

Singh SB, Dutt M, Desai RN (1965) Persistency of milk yield in Hariana cattle. Ind J Vet Sci 35: 249-257

Solkner J, Fuchs W (1987) A comparison of different measures of persistency with special reference to variation of test-day milk yield. Livest Prod Sci 16: 305- 319

Tekerli M, Akinci Z, Dogan I, Akcan A (2000) Factors affecting the shape or lactation curves of Holstein cows from the Balikesir province of Turkey. J Dairy Sci 83: 1381-1386

Torshiz ME (2016) Effects of season and age at first calving on genetic and phenotypic characteristics of lactation curve parameters in Holstein cows. J Anim Sci Technol 58: 8

Williams M, Murphy CP, Sleator RD, Ring SC, Berry DP (2021) Genetic and nongenetic factors associated with lactation length in seasonalcalving, pasture-based dairy cows. J Dairy Sci 104:561-574

Zaman G, Das D, Roy TC (1994) Persistency of first lactation milk yield in a Jersey herd of Assam. J Assam Vet Council 4: 18-21

Zurwan A, Moaeen ud Din M, Bilal G, Khan MS (2017) Estimation of genetic parameters for persistency of lactation in Sahiwal dairy cattle. Pak J Zool 49: 877882 